\title{
PENGARUH LINGKUNGAN KERJA DAN DISIPLIN KERJA TERHADAP KINERJA PEGAWAI PADA DINAS PEKERJAAN UMUM PERUMAHAN DAN ESDM DAERAH ISTIMEWA YOGYAKARTA
}

\author{
Achmad Mukhlisin \\ achmadmuchlisin10@yahoo.com \\ Universitas Ahmad Dahlan \\ Ani Muttaqiyathun \\ animtq@gmail.com \\ Universitas Ahmad Dahlan
}

\begin{abstract}
ABSTRAK
The purpose of this study was to determine the effect of the work environment andwork discipline on employee performance in the Public Works, Housing agency and ESDM DIY both partially and simultaneously (together). The population in this study amounted to 391 employees 198 samples were then taken using a sampling technique the sample is Simple Random Sampling with the Slovin formula. The type of data is data primary and data collection techniques using questionnaires that have been first tested with a test of validity and reliability. Analysis technique the data is multiple linear regression, $t$ test, $f$ test, and determination test. Based on the results of the analysis with statistical tools SPSS V 20 can be used it was concluded that the work environment (X1) and work discipline (X2) variables are good partially (singly) or simultaneously (together) influential significant impact on employee performance (Y) at the Department of Public Works, Housing and ESDM DIY.
\end{abstract}

Keyword: Work Environment; Work Discipline; Performance.

PENDAHULUAN

Dalam sebuah Instansi atau perusahaan SDM merupakan suatu faktor yang sangat penting dalam mencapai sebuah tujuan dari perusahaan atau instansi tersebut. Dalam mencapai tujuan juga tak lepas dari kinerja pegawai. Dan setiap perusahaan atau instansi akan menetapkan standarstandar kerja tertentu demi tercapainya sebuah tujuan. Menetapkan standar bagi tiap instansi akan berbeda satu dengan yang lain. Standar-standar kerja akan berpengaruh terhadap kinerja pegawai. Pemenuhan standar kerja mutlak dilakukan karena hal itu dapat mempengaruhi kelangsungan atau kemakmuran sebuah instansi.

Setiap instansi memerlukan sumber daya untuk mencapai tujuannya. Sumber daya merupakan sumber energi, tenaga, kekuatan (power) yang diperlukan untuk menciptakandaya, gerakan, aktivitas, kegiatan, dan tindakan. Sumber daya tersebut antara lain terdiri atas sumber daya alam, sumber daya finansial, sumber daya ilmu pengetahuan, dan sumber daya manusia (SDM) human resources). SDM merupakan sumber daya yang digunakan untuk menggerakkan dan menyinergikan sumber daya lainnya untuk mencapai tujuan organisasi (wirawan, 2009). Sdm yang baik bisa dinilai dari cara dia berkinerja. Kinerja pada dasarnya adalah apa yang dilakukan pegawai sehingga akan mempengaruhi seberapa besar pegawai itu berkontribusi terhadap instansi. Berkaitan dengan hal itu instansi selalu berusaha meningkatkan kinerja pegawainya. Berbagai cara seperti penerapan disiplin kerja dan penciptaan lingkungan kerja yang kondusif.

Kinerja pegawai merupakan hal yang sangat penting dalam upaya mencapai tujuan instansi. Kinerja yang 
baik akan menciptakan kepuasan kerja tersendiri bagi setiap pegawai. Kinerja adalah tingkat produktifitas seorang karyawan, relatif pada rekan kerjanya, pada beberapa hal dan perilaku yang terkait dengan tugas (Riani, 2013). Sedangkan menurut (wirawan, 2009) kinerja merupakan fungsi dari kompetensi, sikap, dan tindakan. Oleh karena kinerja itu merupakan suatu hal yang sangat penting bagi instansi dalam menunjang kelancaran instansi guna mencapai tujuan dari instansi itu. Semangat yang tinggi dari pegawai sangat membantu dalam terciptanya tujuannya. Kinerja pegawai akan meningkat karena adanya faktor-faktor yang mempengaruhinnya baik faktor internal maupun eksternal yang timbul dari perusahaan yang bersangkutan. Faktor yang mempengaruhi kinerja adalah disiplin kerja.

Menurut Siagian (2004) yang dikutip oleh Koeswara dan Budianto dalam jurnal yang berjudul "Pengaruh lingkungan kerja dan Disiplin Kerja terhadap Kinerja Karyawan Packindo Farma Utama Jakarta" (2011) disiplin kerja merupakan tindakan manajemen untuk mendorong para anggota organisasi memenuhi tuntutan berbagai ketentuan tersebut. Didalam kedisiplinan di berlakuakan peraturan dan hukuman. Peraturan sangat diperlukan untuk memberikan bimbingan terhadap karyawan dalam menciptakan prilaku yang tata tertib yang baik. Dengan adanya semua peraturan yang sudah disusun dan diterapkan oleh instansi, hal ini diharapkan mendorong pegawai dalam bekerja dan mewujudkan apa yang telah menjadi tujuan perusahaan melalui disiplin kerja. Selain disiplin kerja faktor yang juga mempengaruhi kinerja dan menjadi hal terpenting dalam instansi yang harus diperhatikan adalah lingkungan kerja.

\section{Rumusan Masalah}

1. Apakah ada pengaruh lingkungan kerja terhadap kinerja pegawai pada
Dinas Pekerjaan Umum Perumahan dan ESDM DIY?

2. Apakah ada pengaruh disiplin kerja terhadap kinerja pegawai pada Dinas Pekerjaan Umum Perumahan dan ESDM DIY?

3. Apakah ada pengaruh lingkungan kerja dan disiplin kerja secara simultan terhadap kinerja pegawai pada Dinas Pekerjaan Umum Perumahan dan ESDM DIY?

\section{REVIEW LITERATUR DAN HIPOTESIS}

\section{Landasan Teori \\ Lingkungan Kerja}

$\begin{array}{clc}\text { Lingkungan } & \text { kerja dalam } \\ \text { perusahaan sangat penting untuk }\end{array}$ diperhatikan pihak manajemen. Meskipun lingkungan kerja tidak terlibat dalam proses produksi akan tetapi lingkungan kerja mempunyai pengaruh langsung terhadap karyawan yang melaksanakan proses kinerjanya. Lingkungan kerja yang memuaskan dapat meningkatkan kinerja karyawan. Sebaliknya lingkungan kerja yang tidak memadai akan menurunkan kinerja karyawan dan akhirnya tingkat kontribusinya terhadap perusahaan akan menurun. Kondisi lingkungan kerja bisa dikatakan optimal apabila karyawan dapat melaksanakan kegiatan secara optimal, sehat, aman, dan nyaman. Menurut Sutrisno (2009) dalam Suwondo dan Sutanto (2015) lingkungan kerja adalah keseluruhan sarana dan prasarana kerja yang ada di sekitar karyawan yang sedang melakukan pekerjaan yang dapat mempengaruhi pelaksanaan pekerjaan. Menurut Sedarmayanti (2001) dalam Saputro (2011) Lingkungan kerja adalah keseluruhan alat perkakas dan bahan yang dihadapi, lingkungan sekitarnya dimana seseorang bekerja, metode kerjanya, serta pengaturan kerjanya baik sebagai perseorangan maupun sebagai kelompok.

\section{Disiplin Kerja}


Pada umumnya disiplin yang baik terdapat apabila pegawai datang ke kantor dengan teratur dan tepat pada waktunya. Disiplin kerja merupakan dua kata yang memiliki pengertian sendiri sendiri. Oleh karenanya untuk mengupasnya secara mendalam perlu mencermati pemahaman kedua kata tersebut (Sinambela, 2012). Disiplin adalah kegiatan manajemen untuk menjalankan standar-standar organisasional (Handoko, 2014). Menurut (Siagian, 2004) disiplin kerja merupakan tindakan manajemen untuk mendorong para anggota organisasi memenuhi tuntutan berbagai ketentuan tersebut.

\section{Kinerja Pegawai}

Kinerja pegawai merupakan hal yang sangat penting dalam upaya mencapai tujuan organisasi. Kinerja yang baik akan menciptakan kepuasan kerja tersendiri bagi setiap pegawai. Kinerja adalah tingkat produktifitas seorang karyawan, relatif pada rekan kerjanya, pada beberapa hal dan perilaku yang terkait dengan tugas (Riani, 2013). Sedangkan menurut (wirawan, 2009) kinerja merupakan fungsi dari kompetensi, sikap, dan tindakan.

\section{Penelitian Terdahulu}

(2011) yang berjudul "Pengaruh Lingkungan Kerja dan Disiplin Kerja terhadap Kinerja Packindo Farma Utama Jakarta”. Berdasarkan analisisnya menyatakan bahwa:

1. Variabel Lingkungan Kerja (X1), dan Disiplin Kerja (X2) mempunyai pengaruh yang positif dan signifikan terhadap Kinerja (Y) Karyawan Packindo Farma Utama sebesar F hitung $=33.9531>\mathrm{F}$ tabel $=3,20$. Berdasarkan hasil dari determinasi berganda maka diperoleh nilai $\mathrm{R}$ koefisien determinasi sebesar 0.601 hal ini menunjukkan variabel Lingkungan Kerja (X1), dan Disiplin Kerja (X2) mempunyai pengaruh $60 \%$ terhadap Kinerja sedangkan sisanya dipengaruhi oleh variabel lain.

2. Berdasarkan hasil dari perhitungan koefisien korelasi parsial, bahwa variabel Lingkungan Kerja (X1) mempunyai nilai t hitung 2.712897721 $>$ t tabel 2.000. Berdasarkan hasil pengujian tersebut berarti bahwa Lingkungan Kerja (X1) secara parsial mempunyai pengaruh signifikan terhadap Kinerja Karyawan (Y).

3. Berdasarkan hasil dari perhitungan koefisien korelasi parsial, bahwa variabel Disiplin Kerja (X2) mempunyai nilai t hitung 5.427933413 $>\mathrm{t}$ tabel 2.000. Berdasarkan haisil pengujian tersebut berarti bahwa Disiplin Kerja (X2) secara parsial mempunyai pengaruh signifikan terhadap Kinerja Karyawan (Y)

\section{Hipotesis}

H1: Ada pengaruh lingkungan kerja terhadap kinerja pegawai pada Dinas Pekerjaan Umum Perumahan dan ESDM DIY

$\mathrm{H} 2$ : Ada pengaruh disiplin kerja terhadap kinerja pegawai pada Dinas Pekerjaan Umum Perumahan dan ESDM DIY

H3: Ada pengaruh lingkungan kerja dan disiplin kerja secara simultan terhadap kinerja pegawai pada Dinas Pekerjaan Umum Perumahan dan ESDM DIY

\section{METODE PENELITIAN}

\section{Populasi dan Sampel}

Populasi adalah wilayah generalisasi yang terdiri atas obyek/ subyek yang mempunyai kualitas dan karakteristik tertentu yang ditetapkan oleh peneliti untuk dipelajari dan kemudian ditarik kesimpulannya (Sugiono, 2008). Sedangkan menurut pendapat lain, populasi adalah keseluruhan subjek penelitian (Arikunto, 2010) dalam 
Anugrahadi (2011). Populasi dalam penelitian ini adalah jumlah keseluruhan pegawai pada Dinas Pekerjaan Umum Perumahan dan ESDM DIY yang berjumlah 391 .

Sampel adalah bagian dari jumlah dan karakteristik yang dimiliki oleh populasi tersebut (Sugiono, 2008). Sedangkan menurut Arikunto (2010) dalam Anugrahadi (2011), Sampel adalah sebagian atau wakil populasi yang diteliti. Apabila subjeknya kurang dari 100 lebih baik diambil semua sehingga penelitian merupakan penelitian populasi. Sampel dalam penelitian ini adalah sebesar 198 pegawai yang ada pada Dinas Pekerjaan Umum Perumahan dan ESDM DIY yang dijelaskan dalam tekhnik pengambilan sampel.

\section{Definisi Operasional}

1. Variabel Independen

Lingkungan Kerja (Variabel
Independen)
Menurut Sedarmayanti (2001) dalam
Saputro (2011) Lingkungan
kerja adalah keseluruhan alat perkakas
dan bahan yang dihadapi, lingkungan
sekitarnya dimana seseorang bekerja,
metode kerjanya, serta pengaturan
kerjanya baik sebagai perseorangan
maupun sebagai kelompok.
Disiplin Kerja ( Variabel Independen)
Disiplin kerja merupakan dua kata
yang memiliki pengertian sendiri
sendiri. Oleh karenanya untuk
mengupasnya secara mendalam perlu
mencermati pemahaman kedua kata
tersebut (Sinambela, 2012). Disiplin
adalah kegiatan manajemen untuk
menjalankan standar-standar
organisasional (Handoko, 2014).

2. Variabel Dependen

Kinerja Pegawai (Variabel Dependen)

Kinerja adalah tingkat produktifitas seorang karyawan, relatif pada rekan kerjanya, pada beberapa hal dan perilaku yang terkait dengan tugas (Riani,2013). Sedangkan menurut (wirawan, 2009) kinerja merupakan fungsi dari kompetensi, sikap, dan tindakan

\section{Uji Instrumen}

1. Uji Validitas

Uji validitas digunakan untuk mengukur sah atau tidaknya suatu kuesioner. Suatu kuesioner dikatakan valid jika pertanyaan pada kuesioner mampu mengukur sesuatu yang akan diukur apakah pertanyaan dalam kuesioner yang sudah kita buat betulbetul dapat mengukur apa yang hendak kita ukur (Adhila, Fitriani dan Ismanto, 2014). Pengujian validitas umumnya dilakukan dengan menyebarkan kuesioner untuk sampel kecil yaitu sebanyak 30 responden. Dalam hal ini penelitian menggunakan alat analisis SPSS 20

\section{Uji Reliabilitas}

Reliabilitas berkenaan dengan derajat konsistensi dan stabilitasi data atau temuan. Dalam pandangan posivistik (kuantitatif), suatu data dinyatakan reliabel apabila dua atau lebih peneliti dalam obyek yang sama dalam waktu berbeda menghasilkan data yang sama, atau sekelompok data bila dipecah menjadi dua menunjukkan data yang tidak berbeda (Sugiyono, 2008). Analisis ini menggunakan program SPSS 20, dengan alpha 0.6. Untuk menguji reliabilitas dalam । pengujian ini adalah dengan membandinngkan cronbach alpha pada hasil olahan SPSS dengan rule of thumb dari kesepakatan umum koefisien alpha yaitu lebih besar dari 0.6.

\section{Teknik Analisis Data}

\section{Analisis Regresi Berganda}

Analisis regresi linier berganda merupakan analisis data yang menghubungkan dua variabel atau lebih untuk mengetahui besarnya pengaruh dari perubahan variabel bebas terhadap variabel terikat dan dengan bantuan 
program SPSS for windows . dengan menggunakan analisis rgresi linier berganda dapat diketahui pengaruh variabel independent lingkungan kerja (X1), disiplin kerja (X2) terhadap variabel dependent yaitu kinerja pegawai(Y). Adapun rumus untuk menghitung regresi linier berganda adalah sebagai berikut :

$\mathrm{Y}=\mathrm{a}+\mathrm{b}_{1} \mathrm{X}_{1}+\mathrm{b}_{2} \mathrm{X}_{2}+\mathrm{e}$

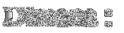

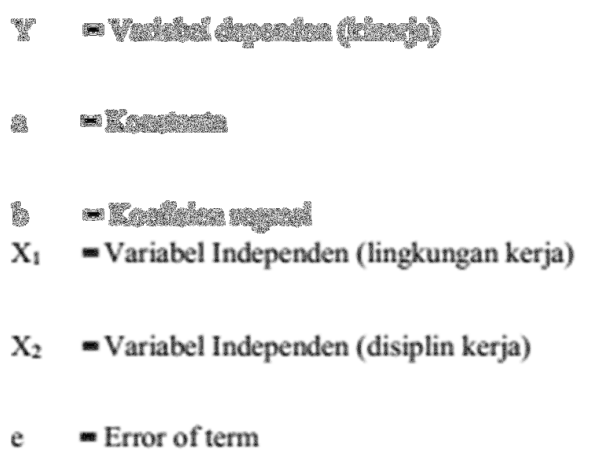

Uji Hipotesis

1. Uji Parsial (Uji T)

Uji t digunakan untuk mengetahui signifikansi pengaruh variabel independen secara individu terhadap variabel dependen untuk menyatakan menolak atau menerima hipotesis. Langkah uji t statistik sebagai berikut:

a). Perumusan hipotesis pertama H01 : Tidak ada pengaruh lingkungan kerja terhadap kinerja pegawai.

$\mathrm{Ha}_{\mathrm{a}}$ : Ada pengaruh lingkungan kerja terhadap kinerja pegawai.

b). Perumusan hipotesis ke dua $\mathrm{H}_{02}$ : Tidak ada pengaruh disiplin kerja terhadap kinerja pegawai.

$\mathrm{Ha}_{2}$ : Ada pengaruh disiplin kerja terhadap kinerja pegawai.

c). Jika sign < alpha maka hipetesis nol (Ho) ditolak dan hipotesis alternatif (Ha) di terima.

d). Jika sign $>$ alpha maka hipotesis nol (Ho) diterima dan hipotesis alternatif
(Ha) diterima. dengan tingkat kenyakinan $95 \%$ atau a $=0,05$

e). Pengambilan keputusan.

2. Uji Simultan (Uji F)

Uji $F$ ini digunakan untuk menghitung signifikansi pengaruh variabel independen secara bersamasama terhadap variabel dependen. Langkah-langkah Uji F statistik sebagai berikut :

a) Perumusan hipotesis

$\mathrm{H}_{0}$ : Tidak ada pengaruh secara simultan lingkungan kerja dan disiplin kerja terhadap kinerja pegawai.

Ha : Ada pengaruh secara simultan lingkungan kerja dan disiplin kerja terhadap kinerja pegawai.

b). Nilai kritis dalam Uji $F$ dengan signifikansi (a ) $=0,05$

c). Jika Sign < alpha maka, H0 ditolak dan menerima Ha Jika Sign > alpha maka, H0 diterima dan menolak $\mathrm{Ha}$ d). Menarik kesimpulan

3. Uji Koefisien Determinasi

Koefisien determinasi digunakan untuk mengukur besarnya proporsi sumbangan variabel bebas (independen) terhadap naik turunnya variabel terikat (dependen) secara bersama-sama ( Sidanti , 2015)

\section{HASIL PENELITIAN DAN PEMBAHASAN}

\section{Hasil Analisis Responden}

Untuk mendapatkan data sampel penulis menggunakan kuesioner yang diberikan kepada sejumlah sampel responden yang bermaksud dengan cara simple random sampling yang dilakukan secara acak tanpa memperhatikan strata yang ada dalam populasi. Sebaran kuesioner sebanyak 200 eksemplar, yang kembali sejumlah 170 eksemplar. Sedangkan yang rusak sebanyak 15 
eksemplar dan yang dapat diolah sebanyak 155 eksemplar

\section{Hasil Penelitian}

1. Hasil Uji Validitas

\begin{tabular}{|c|c|c|c|}
\hline \multirow{2}{*}{ Pernyataan } & r hitung & $\mathrm{r}$ tabel & \multirow{2}{*}{ Keterangan } \\
\hline & $N=30$ & $\mathrm{df}=\mathrm{N}-2=30-2=28$ & \\
\hline Pernyataan21 & 0,532 & 0,374 & Valid \\
\hline Pernyataan24 & 0,769 & 0,374 & Valid \\
\hline Pernyataan26 & 0,616 & 0,374 & Valid \\
\hline 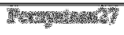 & 霖 & 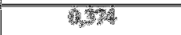 & Wast \\
\hline 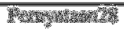 & (n) & Dry & 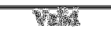 \\
\hline 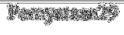 & ars & 6324 & What \\
\hline 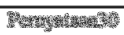 & 6,502 & 32 & Whe晠 \\
\hline
\end{tabular}

Berdasarkan tabel 5.6 di ketahui bahwa seluruh butir pernyataan dari variabel Kinerja (Y) valid karena memiliki nilai $\mathrm{r}$ hitung $>\mathrm{r}$ tabel, $($ pada taraf signifikan $5 \%$, dan $\mathrm{df}=\mathrm{N}-2=$ $30-2=28$ ) yang menunjukkan angka sebesar 0,374. Hal ini menunjukkan bahwa kuesioner telah memenuhi syarat untuk digunakan sebagai pengumpulan data dalam penelitian ini

2. Hasil Uji Reliabilitas

\begin{tabular}{|c|c|c|c|}
\hline Variabel & $\begin{array}{c}\text { Cronbach } \\
\text { alpha }\end{array}$ & Rule of Thumb & Status \\
\hline Lingkungan Kerja $\left(\mathrm{X}_{1}\right)$ & 0,883 & 0,60 & Reliabel \\
\hline Disiplin Kerja ( $\left.\mathrm{X}_{2}\right)$ & 0,831 & 0,60 & Reliabel \\
\hline Kinerja (Y) & 0,841 & 0,60 & Reliabel \\
\hline
\end{tabular}

Dari tabel 5.7 diatas menunjukkan bahwa item pertanyaan dari variabel penelitian berstatus reliabel. Hal ini terlihat dari koefisien Cronbach Alpha bernilai lebih besar dari 0,60 maka instrumen penelitian (Kuesioner) yang digunakan dalam penelitian dinyatakan reliabel. Dengan demikian instrumen penelitian tersebut dapat digunakan untuk meneliti data-data sama pada kondisi relatif sama, dengan probabilitas hasil penelitian yang dapat dipercaya.
3. Hasil Uji Regresi Linier Berganda

\begin{tabular}{|c|c|}
\hline \multirow{2}{*}{ Hasil model } & Unstandardized \\
\cline { 2 - 2 } & Coefficients \\
\hline (Constant) & 1.137 \\
\hline Lingkungan Kerja & .159 \\
\hline Disiplin Kerja & .558 \\
\hline
\end{tabular}

$\mathrm{Y}=1.137+0.159 \mathrm{X}_{1}+0.558 \mathrm{X}_{2}+\mathrm{e}$

$\mathrm{Y}=$ Variabel terikat yang nilainya akan diprediksi oleh variabel bebas. Dalam penelitian ini yang menjadi variabel terikat adalah kinerja para pegawai pada Dina Pekerjaan Umum, Perumahan dan ESDM DIY yang nilainya diprediksi oleh variabel Lingkungan Kerja (X1) dan variabel Disiplin Kerja (X2).

$\mathrm{a}=1,137$ merupakan nilai konstanta, dengan demikian nilai konstanta ini menunjukkan besarnya nilai variabel kinerja para pegawai pada Dinas Pekerjaan Umum, Perumahan dan ESDM DIY jika variabel lain (bebas) sama dengan nol atau konstan.

$\mathrm{b} 1=0.159$ merupakan koefisien arah variabel Lingkungan Kerja (X1) yang mempengaruhi kinerja para pegawai pada Dinas Pekerjaan Umum, Perumahan dan ESDM DIY (Y). Koefisien regresi (b1) sebesar 0.159 dengan tanda positif. Berdasarkan hasil tersebut maka dapat disimpulkan bahwa apabila Lingkungan Kerja (X1) berubah atau naik satu satuan maka kinerja para pegawai pada Dinas Pekerjaan Umum,

Perumahan dan ESDM DIY akan naik sebesar 0.159 dengan asumsi variabel independen lainnya mempunyai nilai sama dengan nol atau konstan. Berdasarkan hasil tersebut maka dapat disimpulkan bahwa apabila perusahaan lebih meningkatkan lingkungan kerja bagi para pegawai maka kinerja pegawai pada Dinas Pekerjaan 
Umum, Perumahan dan ESDM DIY sangat tinggi.

b2 $=0.558$ merupakan koefisien arah variabel Disiplin Kerja (X2) yang mempengaruhi kinerja para pegawai pada Dinas Pekerjaan Umum,

Perumahan dan ESDM DIY (Y). Koefisien regresi (b2) sebesar 0.558 dengan tanda positif. Berdasarkan hasil tersebut maka dapat disimpulkan bahwa apabila Disiplin Kerja (X2) berubah atau naik satu satuan maka kinerja para pegawai pada Dinas Pekerjaan Umum,

Perumahan dan ESDM DIY akan naik sebesar 0.558 dengan asumsi variabel independen lainnya mempunyai nilai sama dengan nol atau konstan. Berdasarkan hasil tersebut maka dapat disimpulkan bahwa apabila perusahaan lebih meningkatkan disiplin kerja bagi para pegawai maka kinerja pegawai pada Dinas Pekerjaan Umum, Perumahan dan ESDM DIY sangat tinggi

\section{Hasil Uji Parsial (Uji T)}

\begin{tabular}{|c|c|}
\hline Model & Sig. \\
\hline Constant & .000 \\
\hline Lingkungan Kerja & .002 \\
\hline Disiplin Kerja & .000 \\
\hline
\end{tabular}

1) Untuk variabel Lingkungan Kerja (X1) , dari hasil olah data menggunakan SPSS 20 nilai signifikan $<$ alpha $(0,002<0,05)$, jadi Lingkungan Kerja (X1) berpengaruh signifikan terhadap Kinerja (Y). Maka dapat diambil kesimpulan $\mathrm{H}_{01}$ ditolak dan $\mathrm{H}_{\mathrm{a}}$ diterima yaitu Ada Pengaruh Lingkungan Kerja terhadap Kinerja Pegawai pada Dinas Pekerjaan Umum, Perumahan dan ESDM DIY.
2) Untuk variabel Disiplin Kerja (X2), dari hasil olah data menggunakan SPSS 20 nilai signifikan < alpha $(0,000<0.05)$, jadi Disiplin Kerja (X2) berpengaruh signifikan terhadap Kinerja (Y). Maka dapat diambil kesimpulan $\mathrm{H}_{02}$ ditolak dan $\mathrm{H}_{2} 2$ diterima yaitu Ada Pengaruh Disiplin Kerja terhadap Kinerja Pegawai pada Dinas Pekerjaan Umum, Perumahan dan ESDM DIY.

5. Hasil Uji Simultan (Uji F)

\begin{tabular}{|ll|c|}
\hline \multicolumn{2}{|l|}{ Model } & Sig. \\
\hline & Regression &, $000^{\mathrm{b}}$ \\
1 & $\begin{array}{l}\text { Residual } \\
\text { Total }\end{array}$ & \\
\hline
\end{tabular}

Berdasarkan hasil olah data menggunakan SPSS 20 nilai signifikansi $<$ alpha $(0,000<0,05)$, jadi $\mathrm{Ha}$ diterima dan Ho ditolak. Dengan demikian dapat disimpulkan bahwa Ada Pengaruh Secara Simultan atau Bersama-sama Lingkungan Kerja dan Disiplin Kerja terhadap Kinerja Pegawai pada Dinas Pekerjaan Umum, Perumahan dan ESDM DIY.

6. Hasil Uji Koefisien Determinasi

\begin{tabular}{|l|ll|}
\hline Model & \multicolumn{2}{|c|}{ R Square } \\
\hline 1 & &, 420 \\
\hline
\end{tabular}

Berdasarkan hasil olah data menggunakan SPSS 20 di dapatkan nilai koefisien determinasi $\mathrm{R}_{2}$ sebesar 0,420 hal ini menunjukkan bahwa sebesar $42 \%$ kinerja pada pegawai Dinas Pekerjaan Umum, Perumahan dan ESDM DIY dipengaruhi oleh variasi kedua variabel yang digunakan, yaitu lingkungan kerja dan disiplin kerja. Sedangkan sisanya $58 \%$ dipengaruhi oleh variabel lainnya. 


\section{Pembahasan}

Berdasarkan hasil uji t, dari kedua variabel yang mempengaruhi kinerja pegawai yaitu lingkungan kerja dan disiplin kerja sebagai berikut : 1) Pengaruh variabel lingkungan kerja terhadap kinerja pegawai pada Dinas Pekerjaan Umum, Perumahan dan ESDM DIY sangatlah signifikan. Hal ini dikarenakan nilai sign $<$ alpha (0,002 0,05), jadi Lingkungan Kerja (X1) berpengaruh signifikan terhadap Kinerja (Y). Maka dapat diambil kesimpulan $\mathrm{H}_{01}$ ditolak dan $\mathrm{H}_{\mathrm{a}}$ diterima yaitu Ada Pengaruh Lingkungan Kerja terhadap Kinerja Pegawai pada Dinas Pekerjaan Umum, Perumahan dan ESDM DIY. Dengan demikian lingkungan kerja yang ada di Instansi meliputi (lingkungan fisik dan non fisik) sudah sangat baik dan maksimal dalam menunjang kinerja pegawai.

2) Pengaruh disiplin kerja terhadap kinerja pegawai pada Dinas Pekerjaan Umum, Perumahan dan ESDM DIY sangatlah signifikan. Hal ini dikarenakan nilai sign < alpha $(0,000$ $<0.05$ ), jadi Disiplin Kerja (X2) berpengaruh signifikan terhadap Kinerja (Y). Maka dapat diambil kesimpulan $\mathrm{H}_{02}$ ditolak dan $\mathrm{H}_{2}$ diterima yaitu Ada Pengaruh Disiplin Kerja terhadap Kinerja Pegawai pada Dinas Pekerjaan Umum, Perumahan dan ESDM DIY. Dengan demikian disiplin kerja para pegawai pada instansi sangat baik. Dan dari hasil uji $F$ dua variabel independent berpengaruh signifikan terhadap variabel dependent. Hal ini dikarenakan nilai signifikansi < alpha $(0,000<0,05), \quad$ jadi Ha diterima dan Ho ditolak. Dengan demikian dapat disimpulkan bahwa Ada Pengaruh Secara Simultan atau Bersama-sama Lingkungan Kerja dan Disiplin Kerja terhadap Kinerja
Pegawai pada Dinas Pekerjaan Umum, Perumahan dan ESDM DIY.

\section{KESIMPULAN DAN SARAN}

\section{Kesimpulan}

Penelitian ini bertujuan untuk mengetahui bagaimana pengaruh variabel lingkungan kerja dan disiplin kerja terhadap kinerja pegawai pada Dinas Pekerjaan Umum, Perumahan dan ESDM DIY. Kesimpulan yang dapat diambil dari penelitian ini adalah :

1. Variabel Lingkungan Kerja secara partial berpengaruh terhadap Kinerja Pegawai pada Dinas Pekerjaan Umum, Perumahan dan ESDM DIY karena nilai sign $<$ alpha $(0,002<$ 0,05), sehingga $\mathrm{H}_{01}$ di tolak dan menerima Ha1.

2. Variabel Disiplin Kerja secara partial berpengaruh terhadap Kinerja Pegawai pada Dinas Pekerjaan Umum, Perumahan dan ESDM DIY karena nilai sign $<$ alpha $(0,000<$ 0,05), sehingga $\mathrm{H}_{02}$ ditolak dan menerima $\mathrm{H}_{\mathrm{a} 2}$.

3. Variabel Lingkungan Kerja dan Disiplin Kerja secara simultan berpengaruh terhadap Kinerja Pegawai pada Dinas Pekerjaan Umum, Perumahan dan ESDM DIY karena nilai signifikansi < alpha $(0,000<0,05)$, jadi Ha diterima dan Ho ditolak

\section{Saran}

1. Bagi Instansi diharapkan untuk lebih memperhatikan lingkungan kerja yang meliputi lingkungan kerja fisik atau non fisik yang dapat menimbulkan rasa aman dan nyaman ketika bekerja sehingga hal itu mampu mendukung kinerja pegawai. Selain itu instansi juga harus meningkatkan kedisiplinan kerja terhadap pegawai agar dapat bertanggung jawab dan bekerja sesuai aturan - aturan yang ada pada instansi tersebut. 
2. Pada penelitian selanjutnya diharapkan tidak hanya menggunakan variabel lingkungan kerja dan disiplin kerja saja. Tetapi, dapat mengikut sertakan variabel lain yang belum diteliti.

3. Pengisian kuesioner yang sebaiknya dipandu secara langsung oleh peneliti sehingga didapatkan data penelitian yang baik

\section{DAFTAR PUSTAKA}

Adhila, Fitroh, Dyah Fitriani, dan Denny Ismanto. 2013. Modul Praktikukm Statistik 2. Yogyakarta : Universitas Ahmad Dahlan.

Anugrahadi.2011. Pengaruh Semangat Kerja dan Disiplin Kerja Terhadap Kinerja Karyawan di CV.Arti Bumi Intaran. Skripsi, Universitas Ahmad Dahlan Yogyakarta.

Handoko, Hani T. 2014. Manajemen Personalia dan Sumber Daya Manusia. Cetakan Keduapuluh Satu. Yogyakarta : BPFE-Yogyakarta.

Harlie, M. 2010. Pengaruh Disiplin Kerja, Motivasi dan Pengembangan Karier terhadap Kinerja Pegawai Negeri Sipil pada Pemerintah Kabupaten Tabalong di Tanjung Kalimantan Selatan. Jurnal, Vol. 11, No.2.

Hidayat, Zainul dan Muchammad Taufiq. 2012. Pengaruh Lingkungan Kerja dan Disiplin Kerja serta Motivasi Kerja Terhadap Kinerja Karyawan Perusahaan Daerah Air Minum (PDAM) Kabupaten Lumajang. Jurnal WIGA, Vol. 2, No.1.

Koeswara, Sonny dan Hery Budianto. 2011. Pengaruh Lingkungan Kerja dan Disiplin Kerja terhadap Kinerja Packindo Farma Utama Jakarta. Jurnal Pasti, Vol.4, No.2.
Putra,Wicaksono. 2012. Didapatkan http://analisisstatistika.blogspot.co.id /2012/09/menentukan-jumlahsampeldengan-rumus.html ( diambil pada tanggal 06 april 2016)

Riani, Laksmi Asri. 2013. Sumber Daya Manusia Masa Kini. Yogyakarta: Graha Ilmu.

Saputro. 2011. Pengaruh Pemberian Kompensasi dan Lingkungan Kerja terhadap Kinerja Karyawan di PDAM Tirtamarta Yogyakarta (Studi Kasus di Bagian Umum PDAM Tirtamarta Yogyakarta). Skripsi, Universitas Ahmad Dahlan Yogyakarta.

Sinambela, Poltak Lijan. 2012. Kinerja Pegawai: Teori Pengukuran dan Implikasi. Cetakan Pertama. Yogyakarta: Graha Ilmu.

Sidanti, Heny. 2015. Pengaruh Lingkungan Kerja, Disiplin Kerja dan Motivasi Kerja terhadap Kinerja Pegawai Negeri Sipil di Sekretariat DPRD Kabupaten Madiun. Jurnal JIBEKA, Vol.9, No.1.

Sugiyono 2008. Metode Penelitian Bisnis. Bandung : Alfabeta.

Sugiyono 2014. Metode Penelitian Kuantitatif, Kualitatif, Dan $R \& D$. Bandung: Alfabeta Suharman. 2013. Pengaruh Karakteristik Individu dan Lingkungan Kerja terhadap Kinerja Pegawai di Lingkungan Kantor Pusat Universitas Gadjah Mada Yogyakarta. Skripsi, Universitas Ahmad Dahlan Yogyakarta.

Suwondo, Indriani Diah dan Eddy Madiono Sutanto. 2015. Hubungan Lingkungan Kerja, Disiplin Kerja, dan Kinerja Karyawan. Jurnal Manajemen dan Kewirausahaan, Vol. 17, No. 2. 
Wirawan. 2009. Evaluasi Kinerja Sumber Daya Manusia : teori aplikasi dan penelitian. Jakarta : Salemba Empat. 